\title{
Species diversity and abundance of plant-dwelling chironomids across hierarchical habitat and seasonal scales in the oxbow lakes of River Tisza, Hungary
}

\author{
Mónika Tóth ${ }^{1, *}$, Diána Árva ${ }^{2}$, Sándor A. Nagy ${ }^{2}$ and András Specziár ${ }^{1}$
}

With 6 figures and 4 tables

\begin{abstract}
In temperate regions, plant-dwelling chironomids can be considered as cyclic colonizers that inhabit seasonally ephemeral submerged and floating-leaved macrophytes. In this study, patterns of abundance and species richness of plant-dwelling chironomids were investigated within and among stands of three macrophyte species in oxbow lakes along the River Tisza (Hungary). Chironomids colonized macrophytes rapidly and most species occupied the habitat before it had completely developed in June. Assemblage structure and abundance of particular species varied considerably between plant species, oxbow lakes and summer months in a characteristic succession from June to August indicating the presence of dynamic selection mechanisms. Abundance of most species, except Endochironomus tendens, total chironomid abundance, within-sample and total species diversity were highest on the submerged plant Ceratophyllum demersum, and most species occurred at the beginning of the colonization succession, in June. The contribution of oxbow lakes $(20.3 \%)$ and the month sampled $(20.3 \%)$ to total chironomid diversity was higher than would be expected by chance alone and the contribution of within (19.7\%) and between samples $(13.5 \%)$ to total chironomid diversity was lower than would be expected by chance alone. We conclude that regional biodiversity conservation action plans should include multiple habitats. Moreover, the significant seasonal species turnover proved the need for seasonal sampling to assess accurately the total diversity of chironomids in the system.
\end{abstract}

Key words: Chironomidae, cyclic colonization, diversity partitioning, balanced hierarchical sampling design, macrophytes, spatio-temporal pattern.

\section{Introduction}

Submerged and floating-leaved macrophytes are the preferred habitat of many aquatic macroinvertebrates. Macrophytes provide living space, shelter from predators and physical disturbances, a substrate for prey (e.g. algae, bacteria, fungi, and small animals), and food for some macroinvertebrates (review in Papas 2007). The presence of macrophytes influences both macroinvertebrate diversity and abundance (Papas 2007, Żbikowski \& Kobak 2007, Tarkowska-Kukuryk
2010). The composition and the abundance of plantdwelling macroinvertebrate communities is also influenced by the architectural and chemical composition, density and structural complexity of macrophyte stands (Cheruvelil et al. 2002, Bogut et al. 2007, Cremona et al. 2008, Hinojosa-Garro et al. 2010, Matias et al. 2010, Tóth et al. 2012).

In temperate regions, submerged and floatingleaved macrophytes are present only at certain times of the year. These plants generally develop from spring to the end of the summer when they collapse

\footnotetext{
Authors' addresses:

${ }^{1}$ Balaton Limnological Institute, MTA Centre for Ecological Research, Klebelsberg K. u. 3, H-8237 Tihany, Hungary

2 Department of Hydrobiology, University of Debrecen, Egyetem tér 1., H-4032 Debrecen, Hungary

${ }^{*}$ Corresponding author; toth.monika@okologia.mta.hu
} 
and survive the winter mainly as seeds, root crowns or small overwintering stems at the bottom or in the sediment (Gettys et al. 2009). Macrophytes can therefore be considered a specific type of predictably ephemeral habitat (Batzer \& Wissinger 1996, Wissinger 1997) that is recolonized every growing season by cyclic colonizers (sensu Batzer \& Wissinger 1996). Cyclic colonization is a migration of organisms between permanent and ephemeral habitats (Batzer \& Wissinger 1996). Different life history strategies and dispersal mechanisms may be involved in this process (review in Bilton et al. 2001). Animals, such as molluscs, crustaceans and some insect taxa, including most plant-dwelling chironomid species, may survive macrophyte-free periods in other habitats within the same aquatic system, most often in the sediment, and then occupy macrophytes when they start to develop (Drake 1982, Gilinsky 1984). Other insect taxa may overwinter in terrestrial habitats and then migrate to and disperse across macrophyte-covered aquatic habitats in spring (Moore \& Lee 1991).

Although cyclic colonization usually occurs at the local scale (i.e. between the benthos and macrophytes) (review in Batzer \& Wissinger 1996), insects with a flying adult stage may disperse over long distances and colonize habitats either as adults or via their deposited eggs (Danell \& Sjoberg 1982, Bilton et al. 2001, Frouz et al. 2003, Solimini et al. 2003). Members of most insect taxa with an aquatic larval stage (e.g. Ephemeroptera, Trichoptera, Odonata and Chironomidae) leave the water as adults. As a result of this type of life cycle (i) each new generation will re-colonize the aquatic habitat, (ii) the flying adults may rapidly colonize new habitats, and (iii) aquatic assemblages of these taxa may change considerably over time. Therefore, in insects with flying adults, each year aquatic macrophytes may be colonised by members of both residential and neighbouring populations (Danell \& Sjoberg 1982, Batzer \& Wissinger 1996, Solimini et al. 2003). Between site dispersal and temporal variability may be even more dynamic in taxa with multivoltine life histories, such as chironomids (Layton \& Voshell 1991, Specziár 2008, Čerba et al. 2010).

The composition and abundance of plant-dwelling macroinvertebrate assemblages are influenced by the structure of the macrophyte stand (Cyr \& Downing 1988, Cremona et al. 2008, Hansen et al. 2010, Hinojosa-Garro et al. 2010, Tóth et al. 2012) and the physical and chemical characteristics of the environment (Ali et al. 2007, Čerba et al. 2010, Tarkowska-Kukuryk 2010). There is also potential for variability of these assemblages along spatial and temporal scales (Beck- ett et al. 1992, Marklund et al. 2001, Balci \& Kennedy 2003, Strayer et al. 2003, Čerba et al. 2010). However, the relative role that different spatial and temporal factors play in structuring assemblage composition, abundance and total diversity is less known. To understand the organization of aquatic communities, spatial and temporal scales should be jointly considered (Erős \& Schmera 2010). Presumably, early colonizers of ephemeral macrophytes come mainly from the local benthos (Batzer \& Wissinger 1996, and references therein), but later the importance of arial colonization from local and metacommunities increases (Danell \& Sjoberg 1982, Solimini et al. 2003). Moreover, since temperate plant-dwelling macroinvertebrate communities are dynamic, and early colonization successions last for $\leq 6$ months (Lake et al. 1989, de Szalay \& Resh 2000, Solimini et al. 2003), the relative role of time (i.e. seasonality) in structuring communities is likely to be higher than in more permanent habitats (e.g. in the benthos).

The aim of this study was to analyse the distributional patterns of plant-dwelling chironomid assemblages in oxbow lakes, densely covered by macrophytes, in the River Tisza system. Specifically, we were interested in (1) to what extent differences between plant species, oxbow lake and season (sampling month) contribute to the variability in chironomid species richness, relative and absolute abundance, and (2) how total chironomid diversity $(\gamma)$ partitions across additive $\alpha$ (within-sample), hierarchical spatial (i.e. between samples, plants and oxbow lakes) and temporal (between months) $\beta$ components. To quantify the relative role of each explanatory variable we performed balanced hierarchical sampling across three plant species, three oxbow lakes and three months with three replicates of each sampling block. Largely monospecific stands of the three most widely distributed plant species in the region were investigated: European white water lily Nymphaea alba L. which has undivided, broad floating leaves; submerged rigid hornwort Ceratophyllum demersum L. which has complex, finely dissected architecture; water chestnut Trapa natans L. which has both submerged and floating leaves.

We hypothesized that (i) different plant species will be colonized by different chironomid assemblages, and those with more robust plant architecture (i.e. $N$. alba and T. natans) may be preferred by miners, whereas those species with a large total plant surface (i.e. C. demersum and T. natans) would support high larval abundance, while those species with a complex plant architecture (i.e. C. demersum and T. natans) 
may support high species richness. We also hypothesized that (ii) species richness will increase with oxbow lake size (i.e. HHT $>$ BKHT $>$ HAG) according to the species area relationship (e.g. Williams 1943, Adler et al. 2005, Matias et al. 2010), (iii) species richness will increase in time due to the prolonged arrival of new colonizers from metacommunities, and (iv) due to the cyclic availability of macrophytes as habitat for chironomids and the short colonization period available, each assemblage metric will vary between oxbow lakes and sampling months.

\section{Material and methods}

\section{Study area}

This study was conducted on three oxbow lakes, Boroszlókerti-Holt-Tisza (BKHT), Hordódi-Holt-Tisza (HHT) and Három-ágú (HAG), on the River Tisza, Hungary (Fig. 1). A large number of oxbow lakes of variable sizes, trophic states and utilization (conservation area, fishery, recreation) are located along the regulated channel of River Tisza. These habitats have been established either naturally or artificially as a result of channel straightening, and they maintain diverse aquatic ecosystems and several of them are protected biodiversity conservation areas.

BKHT is located in the Upper Tisza region $\left(48^{\circ} 05^{\prime} 10^{\prime \prime} \mathrm{N}\right.$; $22^{\circ} 24^{\prime} 41^{\prime \prime}$ E). The channel was cut through in the $19^{\text {th }}$ century during the regulation of the River Tisza which aimed to shorten the flood periods of the river and to decrease flooded areas. Today BKHT is in direct connection with the river and regularly receives fresh water during floods. It has an area of 14 ha and an average depth of $1 \mathrm{~m}$. During the study its shore was covered by diverse marshy vegetation dominated by Glyceria maxima (Hartm.) Holmb., Typha angustifolia L., Schoenoplectus lacustris (L.) Palla, Sparganium erectum L. and Carex spp., while the water surface was covered with patches of submerged and floating-leaved macrophytes composed mainly of $C$. demersum, T. natans and N. alba, and to a smaller extent Potamogeton lucens L., Potamogeton crispus L., Nuphar lutea (L.) and Stratiotes aloides L.

Lakes HHT and HAG are relatively isolated within the man-made Kisköre Reservoir in the Middle Tisza region. Both HHT and HAG are strictly protected because they form part of a bird reserve and are preserved in their semi-natural state. HHT ( $47^{\circ} 39^{\prime} 01^{\prime \prime} \mathrm{N}$; $20^{\circ} 44^{\prime} 42^{\prime \prime} \mathrm{E}$ ) was cut off during the regulation of the river in the second part of the $19^{\text {th }}$ century. It has an area of 37 ha and average depth is $1.2 \mathrm{~m}$. In the last few years, accelerated sedimentation has resulted in a rapid decrease in its maximum depth from $5-8 \mathrm{~m}$ to $<3 \mathrm{~m}$. This change sup-

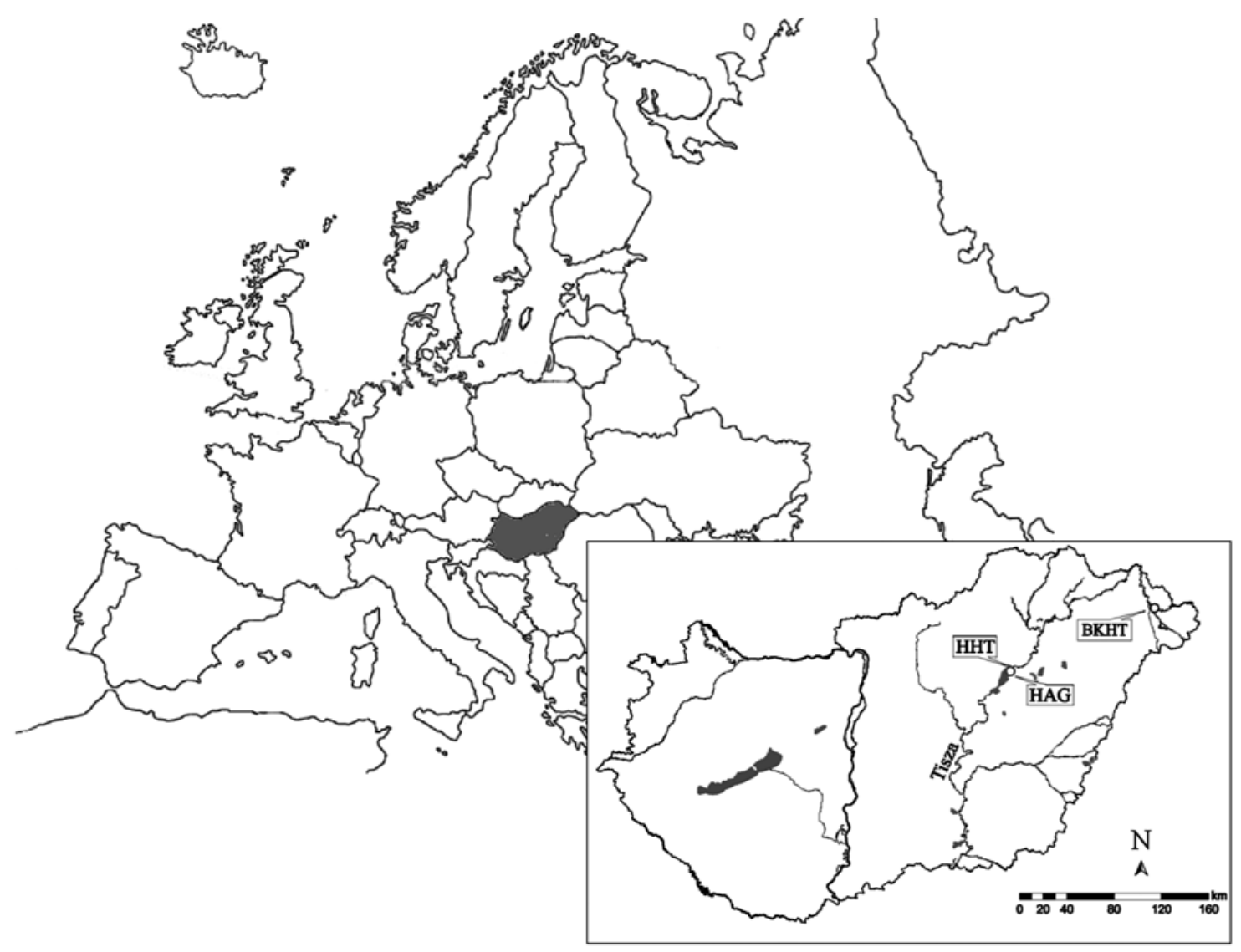

Fig. 1. Location of the investigated oxbow lakes, Boroszló-kerti-Holt-Tisza (BKHT), Hordódi-Holt-Tisza (HHT) and Három-ágú (HAG) of the River Tisza, Hungary. 
Table 1. Hydrological and limnological characteristics of the studied oxbow lakes, Boroszló-kerti-Holt-Tisza (BKHT), Hordódi-Holt-Tisza (HHT) and Három-ágú (HAG) of River Tisza, Hungary.

\begin{tabular}{lccc}
\hline & BKHT & HHT & HAG \\
\hline Surface area (ha) & 14.0 & 37.0 & 11.8 \\
Maximum depth (m) & 4.2 & 3.0 & 1.7 \\
Mean depth (m) & 1.0 & 1.2 & 0.9 \\
Annual water level fluctuation (m) & 1.3 & 0.6 & 0.5 \\
Macrophyte coverage (\%) & & & \\
$\quad$ June & 60 & 55 & 60 \\
July & 75 & 60 & 75 \\
$\quad$ August & 75 & 70 & 85 \\
Water temperature $\left({ }^{\circ} \mathrm{C}\right)$ & & & \\
$\quad$ June & 23.8 & 22.9 & 24.0 \\
July & 24.1 & 23.5 & 25.2 \\
August & 26.7 & 25.4 & 26.8 \\
pH & & & \\
June & 7.9 & 7.5 & 7.3 \\
July & 7.2 & 7.0 & 7.6 \\
August & 7.3 & 7.2 & 8.1 \\
Dissolved oxygen (mg 1 & \\
June & & & \\
July & 8.2 & 7.5 & 7.8 \\
August & 6.6 & 7.9 & 7.6 \\
P and N concentration in the water (mg $1^{-1}$ ) & & \\
Dissolved orthophosphate & $<0.01$ & - & - \\
Total P & 0.062 & - & - \\
Inorganic N & 0.043 & - & - \\
Organic N & 0.449 & - & - \\
\hline
\end{tabular}

ported the development of macrophytes, which have covered the greater part of HHT. During the study, the shore was covered mainly by $T$. angustifolia, G. maxima and $S$. erectum. At the same time, the pond area was strongly overgrown by stands of T. natans, $C$. demersum, Myriophyllum spicatum L. and $N$. alba, supplemented by small patches of P. lucens and Sal-

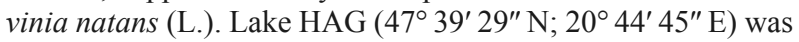
established naturally by the spontaneous cut of a river bend. Its area is 11.8 ha and on average the lake is $0.9 \mathrm{~m}$ deep. The shore of this oxbow lake is covered by diverse marshy vegetation dominated by Phragmites australis (Cavan.) Trin. et Stend., T. angustifolia, G. maxima and $S$. erectum, while in the water T. natans, N. alba, C. demersum, M. spicatum and P. lucens were the most abundant plants.

Physico-chemical characteristics of the BKHT, HHT and HAG are summarized in Table 1.

\section{Sampling}

A balanced hierarchical sampling design was used. Three parallel samples were taken from the monospecific stands of $C$. demersum, N. alba and T. natans in BKHT, HHT and HAG each month from June (i.e. the start of development of macrophytes) to August (i.e. the onset of decomposition of macrophytes) in summer 2008. The total number of samples was 81 (three samples $\times$ three plant species $\times$ three oxbow lakes $\times$ three months).
Equivolume $\left(0.018 \mathrm{~m}^{3}\right)$ samples were collected near the water surface amongst the densest, monospecific macrophyte stands using a Plexiglas box sampler (length $\times$ width $\times$ height: $30 \times 30 \times 20 \mathrm{~cm}$ ). The open sampler was gently submerged into the water and closed, simultaneously cutting all the plants within and preventing the escape of animals. Sampled water and plants were washed through a $0.25 \mathrm{~mm}$ mesh sieve, and then the remaining samples (plants and epiphytic animals) were transferred to plastic containers and carried to the laboratory in cooling bags.

Samples were sorted in the laboratory within 24 hours of sampling. The dry mass of sampled macrophytes was measured after desiccation $\left(60^{\circ} \mathrm{C}, 48 \mathrm{~h}\right)$. Chironomid larvae were preserved in $70 \%$ ethyl-alcohol, mounted on microscopic slides and identified to the lowest possible taxonomic level according to keys of Bíró (1981), Cranston (1982), Wiederholm (1983), Vallenduuk (1999) and Vallenduuk \& Moller Pillot (2002). The nomenclature of Sæther \& Spies (2011) was applied. Abundance (A) of chironomids was expressed as the number of individuals per kg dry mass of macrophytes.

\section{Statistical analysis}

The relationship of relative chironomid abundance (\%) with plant species, oxbow lake and sampling month were investigated by redundancy analysis (RDA) using CANOCO version 4.5 (ter Braak \& Šmilauer 2002). RDA was chosen because a preliminary detrended correspondence analysis (DCA) indicated a relatively short gradient length $(\leq 3.22$ in standard deviation units, see Lepš \& Šmilauer 2003). Relative abundance data were $\arcsin \left(\mathrm{x}^{0.5}\right)$ transformed prior to analyses. Rare chironomid species (i.e. $<0.5 \%$ of the total number of larvae collected) were excluded from the analysis. Explanatory variables (plant species, oxbow lake and sampling month) were re-coded into binary dummy variables (Lepš \& Šmilauer 2003). First, a preliminary overall RDA model was built, which included all potential explanatory variables (Lepš \& Šmilauer 2003). The relative contribution of each variable to the model was assessed by using the forward stepwise selection procedure, and their significance was tested by a Monte-Carlo permutation test with 9,999 permutations under the full model. On the basis of this selection procedure, five (T. natans, June, BKHT, C. demersum, HHT) dummy variables proved to be significant $(p<0.05)$ and one (July) marginally significant $(p=0.055)$. These six variables were retained in the final RDA model. Note that due to collinearity, the dummy variables $N$. alba, HAG and August were used only as supplementary variables. Statistical significance of ordination axes and the whole model were tested using a Monte Carlo permutation test with 9,999 permutations. Next, a series of RDAs and partial RDAs were conducted to partition the effects of plant species, oxbow lake and sampling month on chironomid assemblage composition (Cushman \& McGarigal 2002).

Chironomid abundance and within-sample species richness data were analysed using general linear models in Statistica 8.0 (StatSoft, Inc.). For statistical analyses, abundance data were $\log _{10}(x+1)$ transformed. Effects of plant species, oxbow lake and sampling month on assemblage composition were evaluated using multivariate analysis of variance (MANOVA) under a full factorial design (i.e. including all variations of factor interactions), followed by univariate analyses of variance (ANOVA) by chironomid species also under a full factorial design and completed with a Tukey HDS post hoc test for significant pure 
factor effects. Rare species (i.e. $<0.5 \%$ of the total number of larvae collected) were grouped into a common category called other chironomids. Thus, MANOVA was based on abundance data of 17 common species and the group of other chironomids.

Between sample variance in chironomid abundance and species richness (all species considered; untransformed data) was investigated using three way (i.e. plant species, oxbow lake, sampling month) ANOVA under a full factorial design followed by a Tukey HDS post hoc test for significant pure factor effects. Evaluation of abundance and species richness data was completed using variance component analysis (VCA). This analysis was used to quantify the relative contribution of the plant species, oxbow lake and sampling month (each handled as random-effects factors) and their second and third degree interactions to between sample variability. Since the data was distributed symmetrically, the ANOVA method (expected MS, MS type I; full factorial design) was used for the VCA (Searle et al. 1992).

To examine the relationship between the sampling effort and the observed species richness, sample-based rarefaction (10,000 permutations) was performed with EcoSim 7.72 software (Gotelli \& Entsminger 2011).

Since larger samples tend to include more species (Crist $\&$ Veech 2006), prior to diversity partitioning, the independence of within-sample species richness to deviations in sample size was examined. In the present study, the volume of water sampled was constant. However, the occurrence and abundance of plant-dwelling chironomids is more closely related to the density of macrophytes than to the volume of the water and therefore, chironomid abundance is expressed as per unit plant mass or plant surface area sampled (e.g. Strayer et al. 2003, Čerba et al. 2010, Tarkowska-Kukuryk 2010, Tóth et al. 2012). For species richness estimates, however, the problem is that the amount of macrophytes sampled cannot generally be standardized (due to practical constraints) and species richness data cannot simply be divided by the effective sample size (i.e. sampled plant mass). Since the density of macrophytes varied between the equivolume samples, we tested (1) whether this deviation was associated with spatial and seasonal factors (i.e. plant species, oxbow lake and sampling month), and (2) whether withinsample species richness $\left(\alpha_{\text {samples }}\right)$ depended upon macrophyte density. Macrophyte density proved to vary between plant species and was highest for $T$. natans stands (three way main effect ANOVA, $\mathrm{F}_{2,74}=17.12, p<0.001$; Tukey HDS post hoc test $p<0.05$ ), but not between seasons and oxbow lakes (three way main effect ANOVA, $\mathrm{F}_{2,74}=1.39-3.03, p=0.255-0.054$, respectively). However, since species richness in each sample $(\alpha)$ did not correlate with density of macrophytes (Pearson's correlation, $\mathrm{df}=79, \mathrm{r}=0.074, p=0.408$ ), no adjustment for sample size (i.e. plant mass sampled) was needed.

Consequently, distribution of total chironomid diversity ( $\gamma$ diversity) in the hierarchical habitat levels (i.e. sample, plant species and oxbow lake) and the sampling month was investigated based on an additive diversity partitioning approach (Crist et al. 2003, Gering et al. 2003). According to the hierarchical sampling design, total observed diversity was divided into the following: $\gamma=\alpha_{\text {samples }}+\beta_{\text {samples }}+\beta_{\text {plants }}+\beta_{\text {oxbow lakes }}+\beta_{\text {months }}$, where $\gamma$ is the total number of species identified in the system, $\alpha_{\text {sample }}$ is the mean species richness of all samples, and $\beta_{\text {samples }}$, $\beta_{\text {plants }}, \beta_{\text {oxbow lakes }}$ and $\beta_{\text {months }}$ correspond to the average diversity among sampling units of the four investigated sampling levels, namely, between samples, plant species, oxbow lakes and sampling months, respectively. Observed values of $\alpha$ and $\beta$ di- versity components were tested against the null model distribution obtained from an individual based unrestricted randomization (10,000 randomizations) in PARTITION 3 (Veech \& Crist 2009). Specifically, it was tested whether the observed values of particular $\alpha$ and $\beta$ diversity components significantly differed from chance. A more detailed description of the null model generation and the randomization procedure can be found in Crist et al. (2003).

\section{Results}

\section{Community structure}

Altogether 3088 individuals of 31 chironomid taxa from three subfamilies (four Tanypodinae, four Orthocladiinae and 23 Chironominae) were recorded. Four species, Paratanytarsus sp. (27.2\%), Dicrotendipes lobiger (Kieffer) (17.0\%), Dicrotendipes tritomus (Kieffer) $(11.8 \%$ ) and Endochironomus tendens (Fabricius) $(9.6 \%)$ dominated the plant-dwelling chironomid community, comprising $65.5 \%$ of the total abundance. Rare species were not numerous; there were two singletons and three doubletons in the samples (Table 2). The rarefied species richness curve shows moderate evidence of approaching an asymptote (Fig. 2) suggesting that the total species pool could include a few more species ( $\gamma$ diversity). The number of species per sample varied between $1-14$ (mean \pm SD: $6.1 \pm 2.9 ; \alpha_{\text {samples }}$ ), and the total abundance of larvae varied between 1-168 (38 \pm 35$)$ individuals per sample and 113-17387 (2358 \pm 3634$)$ individuals $\mathrm{kg}^{-1}$ plant dry mass.

Redundancy analysis (full model: $\mathrm{F}=8.93, p$ $<0.001)$ and variation partitioning showed that plant species, oxbow lake and sampling month accounted for $23.9 \%, 8.5 \%$ and $9.6 \%$ of the variance in the rela-

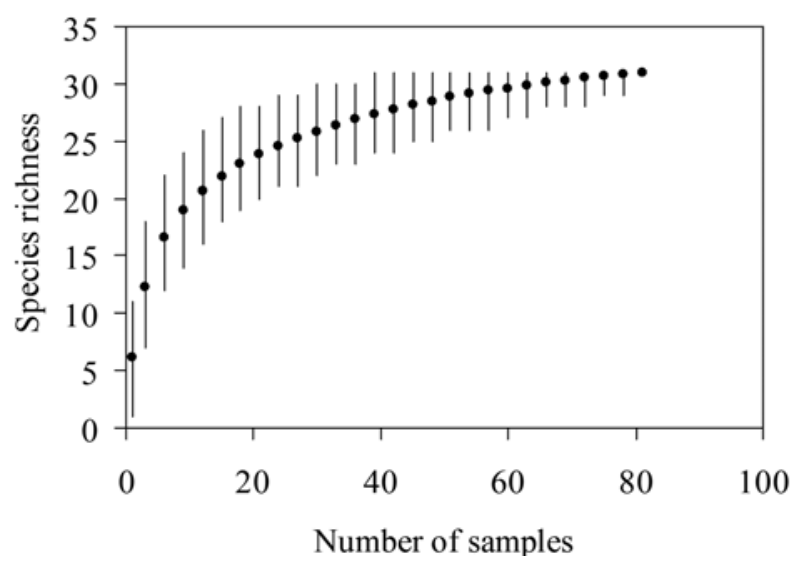

Fig. 2. Rarefied species richness $( \pm 95 \% \mathrm{CI})$ of plant-dwelling chironomids as a function of number of samples in the oxbow lakes of the River Tisza, Hungary. 
Table 2. List of plant-dwelling chironomid species, the abbreviations used in tables and figures, numbers of individuals collected $(\mathrm{N})$, frequency of occurrence in samples (FO\%) and relative abundance (A\%) in the oxbow lakes of the River Tisza, Hungary.

\begin{tabular}{|c|c|c|c|c|}
\hline Species name & Abbreviation & $\mathbf{N}$ & FO\% & $\mathbf{A \%}$ \\
\hline \multicolumn{5}{|l|}{ Tanypodinae } \\
\hline Ablabesmyia longistyla Fittkau 1962 & Abl lon & 2 & 2.5 & 0.1 \\
\hline Ablabesmyia monilis (Linnaeus 1758) & Abl mon & 87 & 25.9 & 2.8 \\
\hline Ablabesmyia phatta (Egger 1863) & Abl pha & 10 & 8.6 & 0.3 \\
\hline Monopelopia tenuicalcar (Kieffer 1918) & Mon ten & 1 & 1.2 & 0.0 \\
\hline \multicolumn{5}{|l|}{ Orthocladiinae } \\
\hline Acricotopus lucens (Zetterstedt 1850) & Acr luc & 2 & 2.5 & 0.1 \\
\hline Cricotopus sylvestris gr. & Cri syl & 83 & 34.6 & 3.1 \\
\hline Cricotopus sp. & Cri sp. & 10 & 8.6 & 0.4 \\
\hline Psectrocladius sordidellus gr. & Pse sor & 60 & 34.6 & 2.3 \\
\hline \multicolumn{5}{|l|}{ Chironominae } \\
\hline Chironomus (Camptochironomus) sp. & CCh sp. & 6 & 1.2 & 0.2 \\
\hline Chironomus annularius agg. & Chi ann & 24 & 1.2 & 0.8 \\
\hline Chironomus luridus agg. & Chi lur & 143 & 32.1 & 3.7 \\
\hline Dicrotendipes lobiger (Kieffer 1921) & Dic lob & 523 & 60.5 & 17.0 \\
\hline Dicrotendipes nervosus (Stæger 1839) & Dic ner & 2 & 2.5 & 0.1 \\
\hline Dicrotendipes tritomus (Kieffer 1916) & Dic tri & 316 & 49.4 & 11.8 \\
\hline Einfeldia pagana (Meigen 1838) & Ein pag & 9 & 3.7 & 0.3 \\
\hline Endochironomus albipennis (Meigen 1830) & Ech alb & 10 & 9.9 & 0.4 \\
\hline Endochironomus tendens (Fabricius 1775) & Ech ten & 500 & 50.6 & 9.6 \\
\hline Glyptotendipes caulicola (Kieffer 1913) & Gly cco & 3 & 2.5 & 0.1 \\
\hline Glyptotendipes cauliginellus (Kieffer 1913) & Gly cgi & 55 & 13.6 & 1.7 \\
\hline Glyptotendipes pallens (Meigen 1804) & Gly pal & 19 & 18.5 & 0.6 \\
\hline Glyptotendipes viridis (Macquart 1834) & Gly vir & 24 & 9.9 & 0.7 \\
\hline Kiefferulus tendipediformis (Goetghebuer 1921) & Kie ten & 21 & 6.2 & 1.1 \\
\hline Parachironomus arcuatus gr. & Pch arc & 63 & 30.9 & 1.9 \\
\hline Phaenopsectra flavipes (Meigen 1818) & Pha fla & 86 & 32.1 & 2.2 \\
\hline Polypedilum cultellatum Goetghebuer 1931 & Pol cul & 13 & 6.2 & 0.5 \\
\hline Polypedilum sordens (van der Wulp 1874) & Pol sor & 138 & 48.1 & 5.8 \\
\hline Synendotendipes dispar gr. & Syn dis & 10 & 6.2 & 0.3 \\
\hline Synendotendipes lepidus (Meigen 1830) & Syn lep & 7 & 2.5 & 0.2 \\
\hline Zavreliella marmorata (van der Wulp 1858) & Zav mar & 1 & 1.2 & 0.0 \\
\hline Paratanytarsus sp. & Pta sp. & 719 & 74.1 & 27.2 \\
\hline Tanytarsus sp. & Tan sp. & 141 & 27.2 & 4.8 \\
\hline Total chironomids & & 3088 & & \\
\hline Number of species & & 31 & & \\
\hline
\end{tabular}

tive abundance data, respectively; while $58 \%$ of the variance remained unexplained. The first axis of the ordination $(22.6 \%$ of the total variance) represented the plant species "gradient"; the high relative abundance of E. tendens was clearly associated with $T$. $n a-$ tans and that of the Paratanytarsus sp. with $C$. demersum. The second axis (10.3\%) mainly captured the seasonal variability and indicated a shift in time from June assemblages, characterised by Ablabesmyia monilis (L.), Cricotopus sylvestris gr., D. tritomus, and Polypedilum sordens (van der Wulp), towards July-August assemblages, which had higher relative abundance of Chironomus luridus agg., D. lobiger and Phaenopsectra flavipes (Meigen) (Fig. 3). The third axis $(4.8 \%$, not shown here) mainly captured the between oxbow lake variability and indicated the weak association of Paratanytarsus sp. with HAG and the association of other (rare) species with BKHT.

\section{Patterns of abundance}

Results of the MANOVA showed that all three investigated factors (i.e. plant species, oxbow lake and sampling month) as well as all possible combinations of 


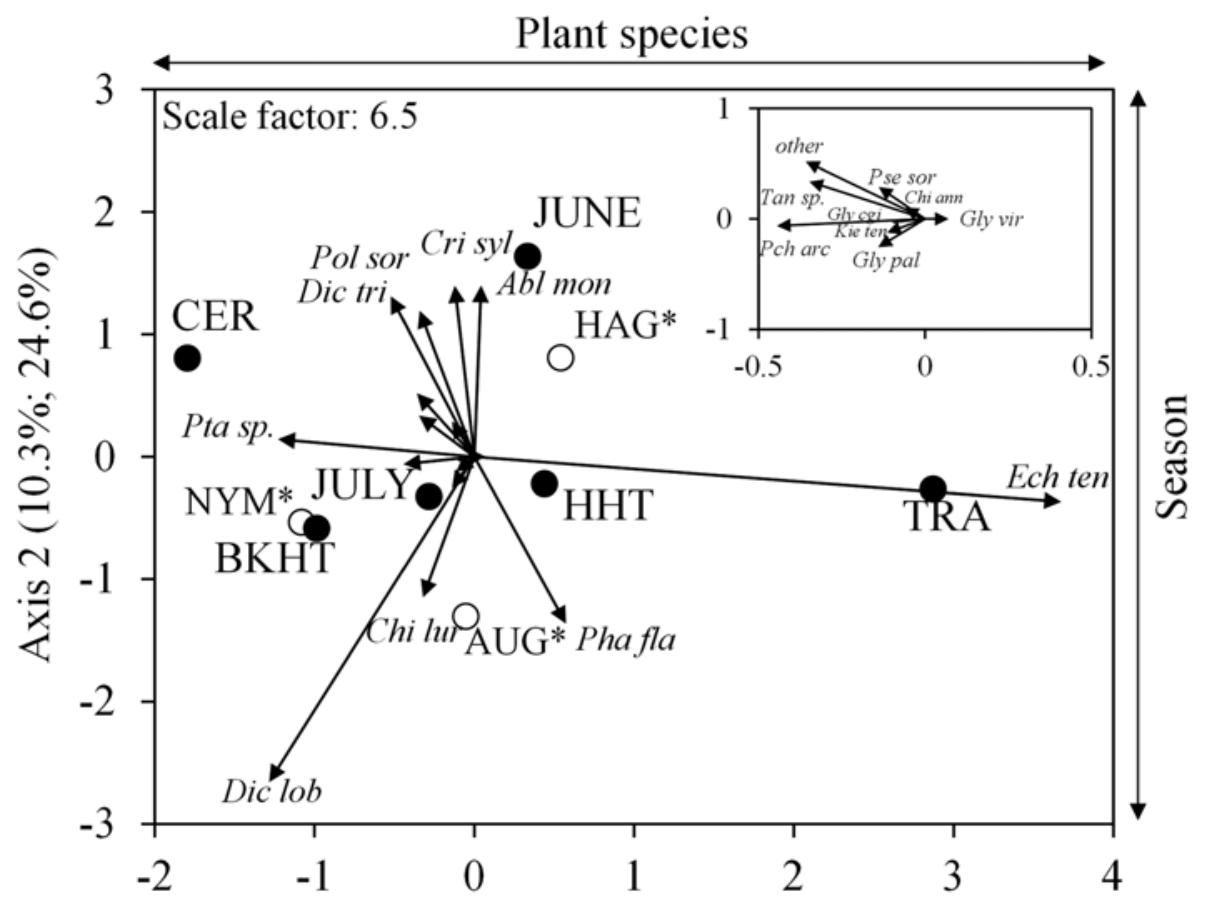

Axis $1(22.6 \% ; 53.7 \%)$

Fig. 3. Redundancy analysis (RDA) plot describing the relationship between relative abundance data (\%) of plant-dwelling chironomids (arrows) and dummy coded explanatory variables (filled circles), plant species, oxbow lake and sampling month in oxbow lakes of the River Tisza, Hungary. Percentage variances represented by axes are indicated in brackets (of species data; of species-explanatory variables relation) after the axis name. Scale factor for biplotting and characteristic environmental gradients represented by the axes are also indicated. Chironomid species with scores close to the centre of the graph are clarified on the small graph in the upper right corner. Explanatory variables marked with "*” were handled as supplementary variables (empty circles) and were not included in the RDA model (due to collinearity). Abbreviations of chironomid species names are given in Table 1, while abbreviations of explanatory variables are as follows: CER - Ceratophyllum demersum; NYM - Nymphaea alba; TRA. Trapa natans; BKHT - Boroszló-kerti-Holt-Tisza; HHT - Hordódi-Holt-Tisza; HAG - Három-ágú; AUG - August.

Table 3. Results of assemblage level MANOVA based on $\log _{10}(x+1)$ transformed abundance data of plant-dwelling chironomids along three predictor factors (plant species, oxbow lake and sampling month) and their interactions in the oxbow lakes of the River Tisza, Hungary.

\begin{tabular}{|c|c|c|c|c|c|}
\hline & Wilks' $\lambda$ & $\mathbf{F}$ & $\mathbf{d f}_{\text {effect }}$ & $\mathbf{d f}_{\text {error }}$ & $p$ \\
\hline Intercept & 0.034 & 58.42 & 18 & 37 & $<0.001$ \\
\hline Plant & 0.038 & 8.52 & 36 & 74 & $<0.001$ \\
\hline Oxbow lake & 0.094 & 4.64 & 36 & 74 & $<0.001$ \\
\hline Month & 0.050 & 7.16 & 36 & 74 & $<0.001$ \\
\hline Plant $\times$ oxbow lake & 0.060 & 2.15 & 72 & 148 & $<0.001$ \\
\hline Plant $\times$ month & 0.138 & 1.34 & 72 & 148 & 0.068 \\
\hline Oxbow lake $\times$ month & 0.069 & 2.00 & 72 & 148 & $<0.001$ \\
\hline Plant $\times$ oxbow lake $\times$ month & 0.017 & 1.46 & 144 & 286 & 0.004 \\
\hline
\end{tabular}

their interactions, except the plant species $\times$ sampling month, had a significant effect on chironomid assemblage abundance and structure (Table 3).

Univariate ANOVAs indicated that abundance of most chironomid species (11 out of the 17 tested) and the total abundance of larvae varied between plant species. Generally, chironomids were most abundant on $C$. demersum, except E. tendens which occurred in highest number on T. natans. Between oxbow lakes variance was important in eight chironomid species and six of these reached their highest abundance in BKHT. Ablabesmyia monilis and Tanytarsus sp. were 


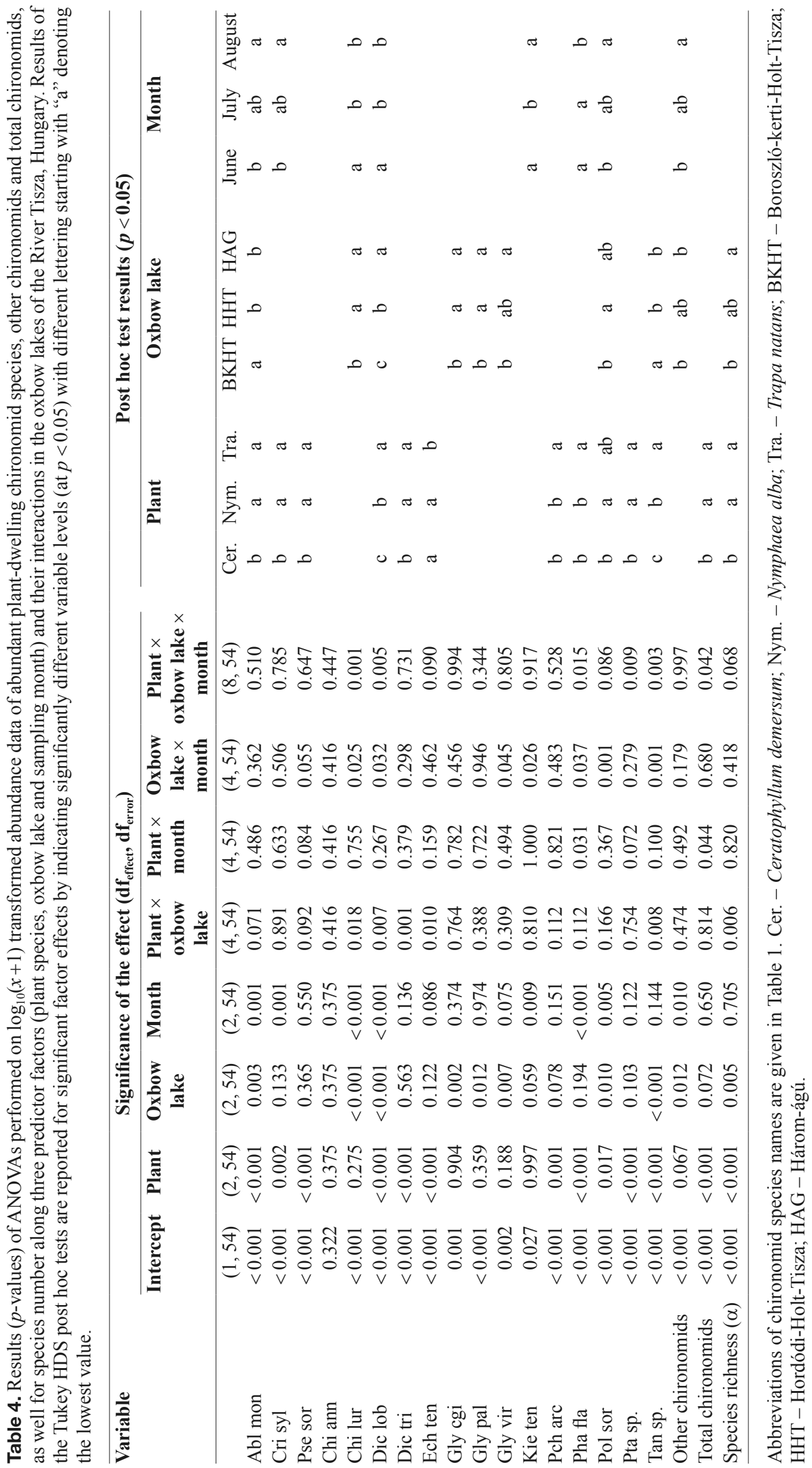




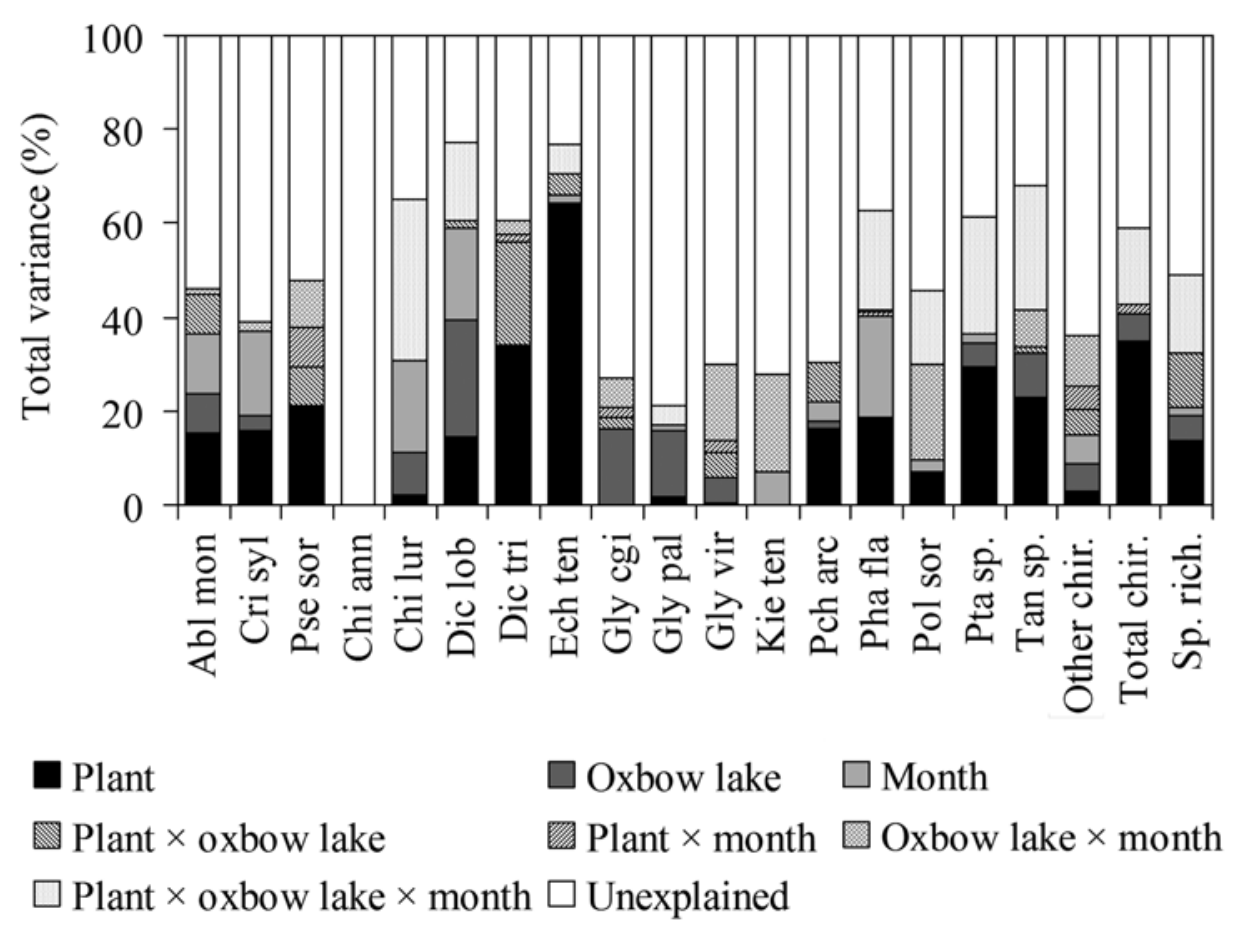

Fig. 4. Partitioning effects of plant species, oxbow lake and sampling month, and their interactions on the variability of abundance and species richness of plant-dwelling chironomids in the oxbow lakes of the River Tisza, Hungary. Abbreviations of chironomid species names are given in Table 1. Other chir. - other chironomids; Total chir. - total chironomids; Sp. rich. - species richness.

more abundant in HHT and HAG. Sampling month was responsible for variations of larval abundance in seven species, but the temporal dynamics of these species were diverse (Table 4).

According to the VCA, plant species accounted for $\geq 10 \%$ of the total variance in the abundance of 10 chironomid species, especially that of $D$. tritomus $(33.6 \%)$ and E. tendens (64.3\%), as well as in the total chironomid abundance (34.7\%). Oxbow lake explained $\geq 10 \%$ of the total variance in the abundance of D. lobiger, Glyptotendipes cauliginellus (Kieffer) and Glyptotendipes pallens (Meigen), whereas sampling month explained $\geq 10 \%$ of the total variance in the abundance of $A$. monilis, Cricotopus sylvestris gr., Chironomus luridus agg., D. lobiger and P. flavipes. Specific factor interactions also proved to be important in some chironomid species. The total explained variance ranged between zero (Chironomus annularius agg.) and $77.4 \%$ (D. lobiger), with a mean of 46.2 $( \pm 21.6 \%, \mathrm{SD})$ at the species level, and it was $59.1 \%$ for the total chironomid abundance (Fig. 4).

\section{Patterns of species diversity}

Mean species number per sample varied with plant species, oxbow lake and their interaction, but not between sampling months. On average, $C$. demersum samples were more species rich than $N$. alba and T. natans samples, and mean number of species was higher in BKHT than in HAG (Table 3). According to the results of the VCA, $5.2 \%$ of the variance of species richness in samples could be attributed to the sole effect of oxbow lake, $13.8 \%$ to the sole effect of plant species and $11.6 \%$ to the shared effect of these two factors (Fig. 4).

Total species richness also varied along habitat and seasonal scales. Most species were found in C. demersum stands (28 species), in BKHT (29 species) and in June (28 species), while fewest species occurred in T. natans stands ( 23 species), in HAG (17 species) and in August (21 species) (Fig. 5). The number of common species was moderate across all plant species (21 species, 67.7\%), oxbow lakes (15 species; $48.4 \%$ ) and sampling months (19 species, $61.3 \%$ ). 


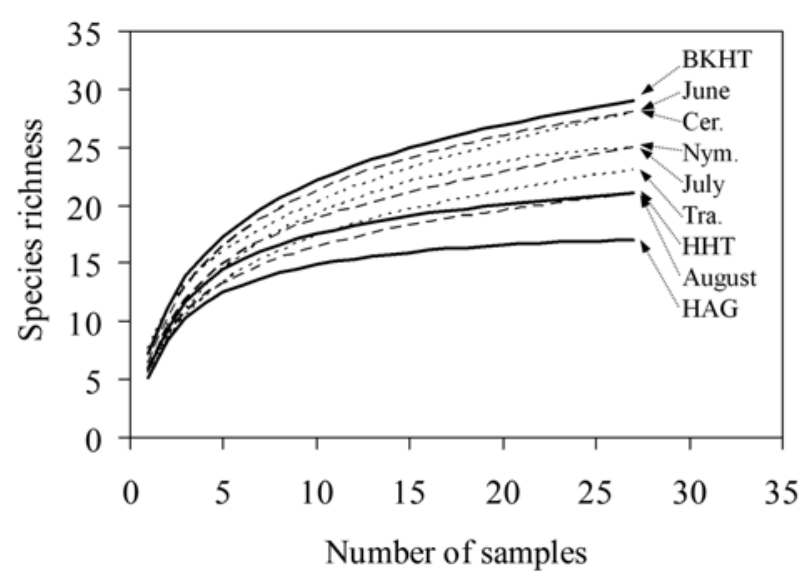

Fig. 5. Rarefied number of species of plant-dwelling chironomids as a function of number of samples by plant species (dotted lines), oxbow lakes (continuous lines) and sampling month (broken lines) in the oxbow lakes of the River Tisza, Hungary. Cer. - Ceratophyllum demersum; Nym. - Nymphaea alba; Tra. - Trapa natans; BKHT - Boroszló-kerti-Holt-Tisza; HHT Hordódi-Holt-Tisza; HAG - Három-ágú.

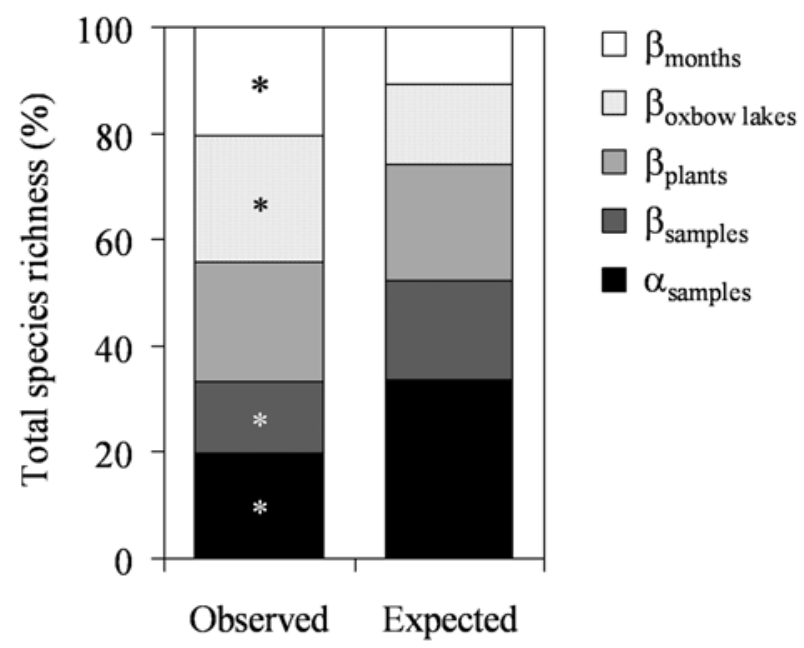

Fig. 6. Relative contribution of additive $\alpha$ and $\beta$ diversity components to the total observed species richness of plant-dwelling chironomid community in the oxbow lakes of the River Tisza (Hungary) at four hierarchical sampling scales: sample, plant species, oxbow lake and sampling month. Significant deviations from the randomization based null pattern are denoted with asterisks.

Species diversity significantly differed from that predicted by the null model. Results of diversity partitioning suggested that higher diversity was associated with habitat (oxbow lake) and season than assumed, and species diversity of small-scale habitat patches was relatively low. Namely, $\alpha_{\text {samples }}(19.7 \% ; p<0.001)$ and $\beta_{\text {samples }}(13.5 \% ; p<0.001)$ were lower and $\beta_{\text {oxbow }}$ lakes $(23.9 \% ; p<0.001)$ and $\beta_{\text {months }}(20.3 \% ; p<0.001)$ were higher than expected by the chance alone, while $\beta_{\text {plants }}(22.6 \% ; p=0.183)$ did not differ from its expected value (Fig. 6).

\section{Discussion}

In temperate regions, plant-dwelling chironomids act as cyclic colonizers as they inhabit seasonally ephemeral aquatic macrophytes. In the oxbow lakes of River Tisza colonization was rapid and most species occupied the habitat before it had completely developed in June. Assemblage structure and abundance of species varied considerably between plant species and oxbow lakes and temporally, suggesting the presence of dynamic selection mechanisms and succession. The contribution of oxbow lakes and sampling months $\beta$ components to the total $(\gamma)$ chironomid diversity was higher than would be expected by chance alone. However, observed patterns did not fully match with the hypotheses of the present study.

Relative abundance of chironomids (i.e. percent composition of the assemblage) varied mainly across plant species and the RDA reflected the strong association of $E$. tendens-dominated assemblages with T. natans contrary to the predominance of Paratanytarsus sp. in C. demersum and N. alba stands. Since larvae of Paratanytarsus sp. are epiphytic collectorfilterers, their high abundance may indicate a rich periphyton or phytoplankton (Čerba et al. 2010). This taxon dominated in BKHT. Larvae of $E$. tendens often mine into soft or damaged leaves and stems of macrophytes (Moller Pillot 2009). The bulbous buoyancy stems and floating leaves of $T$. natans could provide particularly good conditions for plant-miners (Kondo \& Hamashima 1992).

The role of plant species associations and degree of dissection of their leaves in structuring macrophytedwelling invertebrate assemblages is antinomic (e.g. Cyr \& Downing 1988, and references therein). Many researchers argue that environmental conditions, food resource, habitat heterogeneity (i.e. complexity, size and density of plant patches) and, in particular, the total colonisable plant surface area might play a more important role in structuring macroinvertebrate assemblages than which macrophytes they inhabit (Cyr \& Downing 1988, Lalonde \& Downing 1992, Pieczyńka et al. 1999, Tarkowska-Kukuryk \& Kornijów 2008). A previous investigation on taxonomically heterogeneous plant stands in the same oxbow system of the River Tisza supported the latter suggestion for structuring chironomid communities (Tóth et al. 2012). 
Our observations based on highly monospecific macrophyte stands agree with this idea, which emphasizes the strong influence of the architectural complexity of plants (e.g. Krecker 1939, Cheruvelil et al. 2002, Hansen et al. 2010, Hinojosa-Garro et al. 2010). Relative abundance, abundance of most chironomid species, total chironomid abundance, sample level $\alpha$ and total species richness all varied between plant species. Generally, most of these metrics reached their highest values in the stands of $C$. demersum, which is a submerged macrophyte with highly complex, finely dissected architecture. Due to its more complex architecture (i.e. having both submerged and floating leaves), it might be supposed that $T$. natans would have higher species richness and total larval abundance than $N$. alba, which has only simple floating leaves, but this was not the case. In fact, species richness was higher in N. alba stands than in T. natans. Our results agree with those of Cremona et al. (2008) who found significantly higher macroinvertebrate abundance on submerged than on floating-leaved macrophytes.

Although total chironomid abundance was the same between oxbow lakes, the species in each of the three oxbow lakes differed notably and only $48.4 \%$ of species occurred in all three. This result indicates significant species turnover over at this scale. Based on the RDA, chironomid assemblages of HHT and HAG were more similar to each other than to that of BKHT. This pattern reflects the relative position of these oxbow lakes, as HHT and HAG lie close to each other while BKHT is about $270 \mathrm{~km}$ upstream. Since HHT and HAG are located in the centre of a large man-made reservoir (Kisköre Reservoir), which provides a diverse set of aquatic habitats for chironomids, a more diverse secondary metacommunity colonization might be expected than BKHT as it is more isolated from other lentic habitats. However, the results contradict this hypothesis. Most species, and especially the rare species, occurred in BKHT, and also, the $\alpha$ diversity (i.e. mean species richness of samples) was highest in this oxbow lake. This pattern also contradicts the general species area relationship (e.g. Williams 1943, McArthur \& Wilson 1963, Adler et al. 2005, Matias et al. 2010), which suggest the highest number of species would be expected from HHT as its surface area is more than 2.5 times larger than BKHT and HAG. Differences in the species pools were most likely related to differences in environmental conditions (water chemistry, food resource and predation) of the three oxbow lakes. However, for a better understanding of the roles that habitat size, complexity and other environmental factors play in cyclic colonization of chironomid species, controlled experiments using artificial substrates of different levels of complexity and periphyton quality are required.

Since many chironomid species have multivoltine life cycles and specific environmental needs, considerable seasonal succession was apparent in the assemblages. Such variability is especially likely in assemblages inhabiting habitats experiencing rapid change (Beckett et al. 1992, Balci \& Kennedy 2003, Čerba et al. 2010). In our study $C$. sylvestris was initially at high abundance but declined as the season progressed. Other studies have found similar trends as Cricotopus species require plant surfaces free of sediment as increasing amounts of sedimented particles reduces the availability of the periphyton and causes a rapid decline in the abundance of these non-mining phytophages (Balci \& Kennedy 2003, Čerba et al. 2010, Tarkowska-Kukuryk 2010).

As expected, time (i.e. sampling month) had a strong effect on total species richness. However, in contrary to the null hypothesis, neither the species richness nor the total abundance of larvae increased with time. In fact, total species richness decreased notably from June to August, and $90 \%$ of species were represented in the June samples. This indicates rapid colonization of macrophytes by chironomids from the benthos. Our data did not provide clear evidence on the role of metacommunity colonizers. Since only three new species appeared after June, the relatively high species turnover through time was due to environmental filtering and differences in phenology, than to prolonged colonization from metacommunities. Čerba et al. (2010) identified three main colonization events during the three months of M. spicatum stands, which were mostly from local populations. However, there was a characteristic succession of chironomid assemblages during the vegetation season. These patterns suggest that change in habitat quality was strongly selective and resulted in the decrease in chironomid species and the observed succession of larval assemblages. Unfortunately, we do not have data to characterize these mechanisms. Based on other studies, chironomids can be considered as early colonizers (Layton \& Voshell 1991) that then are strongly affected by other invertebrate groups (Lake et al. 1989). However, since only species richness and not the total abundance of larvae decreased during the vegetation period, it is likely that species-specific selection mechanisms operated rather than group-specific mechanisms. A further interesting finding is that the $\alpha$ diversity (i.e. mean species richness of samples) remained stable throughout 
the study. This, together with strongly decreasing total species richness, resulted in the convergence of chironomid assemblages at small spatial scale (i.e. between samples) in time.

In conclusion, diversity partitioning showed that there is a notable species turnover between oxbow lakes and through time in the backwater system of the River Tisza. Between oxbow lakes variability suggests differences in both the species pool of potential colonizers and the environmental characteristics of the habitats. Considering the high species turnover across oxbow lakes, regional biodiversity conservation projects should include multiple habitats and in particular the species rich BKHT should receive a high priority. Significant seasonal species turnover highlights the limitations of single surveys and proves the necessity of seasonal sampling to assess the total chironomid diversity of this system.

\section{Acknowledgements}

We are grateful to Pál Boda, Adrienn Tóth, Kristóf Málnás, Csaba Schnitchen, Tamás Lőrincz and Lajos Gál for their indispensable assistance in the fieldwork and Stephen J. Brooks for correcting the English in the manuscript. The study was supported by grants from the Hungarian Scientific Research Fund (OTKA CNK 80140 and K 104279).

\section{References}

Adler, P. B., White, E. P., Lauenroth, W. K., Kaufman, D. M., Rassweiler, A. \& Rusak, J. A., 2005: Evidence for a general species-time-area relationship. - Ecology 86: 2032-2039.

Ali, M. M., Mageed, A. A. \& Heikal, M., 2007: Importance of aquatic macrophyte for invertebrate diversity in large subtropical reservoir. - Limnologica 37: 155-169.

Balci, P. \& Kennedy, J. H., 2003: Comparison of chironomids and other macroinvertebrates associated with Myriophyllum spicatum and Heteranthera dubia. - J. Freshw. Ecol. 18: $235-247$.

Batzer, D. P. \& Wissinger, S. A., 1996: Ecology of insect communities in nontidal wetlands. - Annu. Rev. Entomol. 41: 75-100.

Beckett, D. C., Aartila, T. P. \& Miller, A. C., 1992: Seasonal change in plant-dwelling Chironomidae and Naididae in a Wisconsin lake. - J. Freshw. Ecol. 7: 45-57.

Bilton, D. T., Freeland, J. R. \& Okamura, B., 2001: Dispersal in freshwater invertebrates. - Annu. Rev. Ecol. Syst. 32: $159-181$.

Bíró, K., 1981: Az árvaszúnyoglárvák (Chironomidae) kishatározója. - In: Felföldy, L. (ed.): Vízügyi Hidrobiológia 11. - VÍZDOK, Budapest pp. 1-229. (in Hungarian)

Bogut, I., Vidaković, J., Palijan, G. \& Čerba, D., 2007: Benthic macroinvertebrates associated with four species of macrophytes. - Biologia 62: 600-606.

Čerba, D., Mihaljević, Z. \& Vidaković, J., 2010: Colonisation of temporary macrophyte substratum by midges (Chironomidae: Diptera). - Ann. Limnol., Int. J. Lim. 46: 181-190.
Cheruvelil, K. S., Soranno, P. A., Madsen, J. D. \& Roberson, M. J., 2002: Plant architecture and epiphytic macroinvertebrate communities: the role of an exotic dissected macrophyte. J. N. Am. Benthol. Soc. 21: 261-277.

Cranston, P. S., 1982: A key to the larvae of the British Orthocladiinae (Chironominae). - Freshw. Biol. Assoc. Sci. Publ. 45: $1-152$.

Cremona, F., Panas, D. \& Lucotte, M., 2008: Biomass and composition of macroinvertebrate communities associated with different types of macrophyte architectures and habitats in a large fluvial lake. - Fundam. Appl. Limnol. 171: 119-130.

Crist, T. O. \& Veech, J. A., 2006: Additive partitioning of rarefaction curves and species-area relationships: unifying $\alpha-$, $\beta$ - and $\gamma$-diversity with sample size and habitat area. - Ecol. Lett. 9: 923-932.

Crist, T. O., Veech, J. A., Summerville, K. S. \& Gering, J. C., 2003: Partitioning species diversity across landscapes and regions: a hierarchical analysis of $\alpha, \beta$ and $\gamma$ diversity. - Am. Nat. 162: 734-743.

Cushman, S. A. \& McGarigal, K., 2002: Hierarchical, multiscale decomposition of species-environment relationships. Landscape Ecol. 17: 637-646.

Cyr, H. \& Downing, J. A., 1988: The abundance of phytophilous invertebrates on different species of submerged macrophytes. - Freshw. Biol. 20: 365-374.

Danell, K. \& Sjoberg, K., 1982: Successional patterns of plants, invertebrates and ducks in a man made lake. - J. Appl. Ecol. 19: $395-409$.

Darby, R. E., 1962: Midges associated with California rice fields, with special reference to their ecology (Diptera: Chironomidae). - Hilgardia 31: 1-206.

de Szalay, F. A. \& Resh, V. H., 2000: Factors influencing macroinvertebrate colonization of seasonal wetlands: responses to emergent plant cover. - Freshw. Biol. 45: 295-308.

Drake, C. M., 1982: Seasonal dinamics of Chironomidae (Diptera) on the bulrush Schoenoplectus lacustris in a chalk stream. - Freshw. Biol. 12: 225-240.

Erős, T. \& Schmera, D., 2010: Spatio-temporal scaling of biodiversity and the species-time relationship in a stream fish assemblage. - Freshw. Biol. 55: 2391-2400.

Frouz, J., Matěna, J. \& Ali, A., 2003: Survival strategies of chironomids (Diptera: Chironomidae) living in temporary habitats: a review. - Eur. J. Entomol. 100: 459-465.

Gering, J. C., Crist, T. O. \& Veech, J. A., 2003: Additive partitioning of species diversity across multiple spatial scales: implication for regional conservation of biodiversity. - Conserv. Biol. 17: 488-499.

Gettys, L. A., Haller, W. T. \& Bellaud, M. (eds), 2009: Biology and control of aquatic plants: a best management practices handbook. - Aquatic Ecosystem Restoration Foundation, Marietta GA, pp. 1-210.

Gilinsky, E., 1984: The role of fish predation and spatial heterogeneity in determining benthic community structure. - Ecology 65: 455-468.

Gotelli, N. J. \& Entsminger, G. L., 2011: EcoSim: Null Models Software for Ecology, Version 7. - Acquired Intelligence Inc. \& Kesey-Bear, Jericho, VT 05465. Available at: http://garyentsminger.com/ecosim.htm (accessed 15 November 2011).

Hansen, J. P., Wikström, S. A., Axemar, H. \& Kautsky, L., 2010: Distribution differences and active habitat choices of invertebrates between macrophytes of different morphological complexity. - Aquat. Ecol. 45: 11-22. 
Hinojosa-Garro, D., Mason, C. F. \& Underwood, G. J. C., 2010: Influence of macrophyte spatial architecture on periphyton and macroinvertebrate community structure in shallow water bodies under contrasting land management. - Fundam. Appl. Limnol. 177: 19-37.

Kondo, S. \& Hamashima, S., 1992: Habitat preferences of four chironomid species associated with aquatic macrophytes in an irrigation reservoir. - Aquat. Ecol. 26: 371-377.

Krecker, F. H., 1939: A comparative study of the animal population of certain submerged aquatic plants. - Ecology 20: 553-562.

Lake, P. S., Bayly, I. A. E. \& Morton, D. W., 1989: The phenology of a temporary pond in western Victoria, Australia, with special reference to invertebrate succession. - Arch. Hydrobiol. 115: 171-202.

Lalonde, S. \& Downing, J. A., 1992: Phytofauna of eleven macrophyte beds of differing trophic status, depth, and composition. - Can. J. Fish. Aquat. Sci. 49: 992-1000.

Layton, R. J. \& Voshell, J. R., 1991: Colonization of new experimental ponds by benthic macroinvertebrates. - Environ. Entomol. 20: 110-117.

Lepš, J. \& šmilauer, P., 2003: Multivariate analysis of ecological data using CANOCO. - Cambridge University Press, New York, pp. 1-269.

Marklund, O., Blindow, I. \& Hargeby, A., 2001: Distribution and diel migration of macroinvertebrates within dense submerged vegetation. - Freshw. Biol. 46: 913-924.

Matias, M. G., Underwood, A. J., Hochuli, D. F. \& Coleman, R. A., 2010: Independent effects of patch size and structural complexity on diversity of benthic macroinvertebrates. Ecology 91: 1908-1915.

McArthur, R. H. \& Wilson, E. O., 1963: An equilibrium theory of insular zoogeography. - Evolution 17: 373-387.

Moller Pillot, H. K. M., 2009: Chironomid larvae. Biology and ecology of the Chironomini. - KNNV Publishing, Zeist, pp. 1-270.

Moore, M. V. \& Lee, R. E. Jr., 1991: Surviving the big chill: overwintering strategies of aquatic and terrestrial insects. Am. Entomol. 37: 111-118.

Papas, P., 2007: Effect of macrophytes on aquatic invertebrates - a literature review. - Technical Report Series No. 158, Arthur Rylah Institute for Environmental Research, Melbourne, Victoria, pp. 1-22.

Pieczyńska, E., Kołodziejczyk, A. \& Rybak, J. I., 1999: The responses of littoral invertebrates to eutrophication-linked changes in plant communities. - Hydrobiologia 391: 9-21.

Sæther, O. A. \& Spies, M., 2011: Fauna Europaea: Chironomidae. - In: de Jong, H. (ed.): Fauna Europaea: Diptera, Nematocera. Fauna Europaea version 2.4. Available at: http:// www.faunaeur.org (accessed 10 September 2012)
Searle, S. R., Casella, G. \& McCulloch, C. E., 1992: Variance Components. - Wiley, New York, pp. 1-501.

Solimini, A. G., Ruggiero, A., Bernardini, V. \& Carchini, G., 2003: Temporal pattern of macroinvertebrate diversity and production in a man made shallow lake. - Hydrobiologia 506-509: 373-379.

Specziár, A., 2008: Life history patterns of Procladius choreus, Tanypus punctipennis and Chironomus balatonicus in Lake Balaton. - Ann. Limnol., Int. J. Limnol. 44: 181-188.

Strayer, D. L., Lutz, C., Malcom, H. M., Munger, K. \& Shaw, W. H., 2003: Invertebrate communities associated with a native (Vallisneria americana) and an alien (Trapa natans) macrophyte in a large river. - Freshw. Biol. 48: 1938-1949.

Tarkowska-Kukuryk, M., 2010: Epiphytic chironomids on rigid hornwort (Ceratophyllum demersum L.) - the relation between the community structure and lake status. - Oceanol. Hydrobiol. St. 39: 117-133.

Tarkowska-Kukuryk, M. \& Kornijów, R., 2008: Influence of spatial distribution of submerged macrophytes on Chironomidae assemblages in shallow lakes. - Pol. J. Ecol. 56: $569-579$.

ter Braak, C. J. F. \& Šmilauer, P., 2002: CANOCO reference manual and CanoDraw for Windows user's guide: software for canonical community ordination, version 4.5. - Microcomputer Power, Ithaca, New York, pp. 1-500.

Tóth, M., Móra, A., Kiss, B., Dévai, Gy. \& Specziár, A., 2012: Are macrophyte-dwelling Chironomidae (Diptera) largely opportunistic in selecting plant species? - Eur. J. Entomol. 109: $247-260$.

Vallenduuk, H. J., 1999: Key to the larvae of Glyptotendipes Kieffer (Diptera, Chironomidae) in Western Europe. - Privately published, Lelystad, 1-46.

Vallenduuk, H. J. \& Moller Pillot, H. K. M., 2002: Key to the larvae of Chironomus in Western Europe. - RIZA rapport 97.053, Lelystad, pp. 1-20.

Veech, J. A. \& Crist, T. O., 2009: PARTITION: software for hierarchical partitioning of species diversity, version 3.0. Available at: http://www.users.muohio.edu/cristto/partition. htm (accessed 16 July 2012).

Wiederholm, T., 1983: Chironomidae of the Holarctic region. Keys and diagnoses. Part 1. Larvae. - Ent. Scand. Suppl. 19: $1-457$.

Williams, C. B., 1943: Area and number of species. - Nature 152: $264-267$.

Wissinger, S. A., 1997: Cyclic colonization in predictably ephemeral habitats: a template for biological control in annual crop systems. - Biol. Control 10: 4-15.

Żbikowski, J. \& Kobak, J., 2007: Factors influencing taxonomic composition and abundance of macrozoobenthos in extralittoral zone of shallow eutrophic lakes. - Hydrobiologia 584: 145-155. 